\title{
ARTWORK IN ART EDUCATION
}

\author{
Kristýna Říhová \\ Mgr., Department of Art Education, Faculty of Education, Charles University, Prague (Czech Republic)
}

\begin{abstract}
The presented research mainly addresses the process of artwork interpretation in art education. Attention is paid to the didactic transformation by which the artwork becomes the subject of education.

This process is explored in the relationship between the students/viewers, the teachers/art educators and the unique artwork itself. The process of artwork interpretation is analysed in a concrete teaching situation in which students are placed at the centre of their learning experiences (the subordination of teaching to learning).

The poster is based on the results of two studies exploring the use of art in art education. In both studies, the crucial question is: What is the space for students' voices, their empirical viewership and their critical thinking in art education?

The research outcomes also reflect the field discourse of art education didactics, especially in relation to functional visual literacy. Visual studies and the theory of art education are the discourses that guide the theoretical framework of the research.
\end{abstract}

Keywords: Art education, interpretation, discourse-based educational models, critical thinking, functional visual literacy.

\section{Introduction}

Multiple literacies emphasizing functional visual, cultural and social literacies and critical and reflective thinking are necessary to understand communication exchanges in visual language systems as well as to understand the relationships and existential controversies of the "natural" world today. In light of these tendencies, the concept of culture as an anthropological complex is broadening for gallery and museum education as part of art education in school. (Fulková 2013) Encounters with an artwork bring a series of challenging questions to education. For example, ethical issues or the concept of intertextuality that points to the fact that artwork interpretation is unstable and the meaning of artworks is constantly changing.

In the paper, the involvement of contemporary art in art education is explored on two levels.

The first level comes from a case study based on the reflection of the educational program and its extension to school education at the second level of primary school. The gallery education "Faces - the Phenomenon of the Face in Video Art" at the Rudolfinum Gallery in Prague. (Ríhová, Svatošová 2012) This part of the research presents the outputs of the analysis of one of the possible ways to involve art in teaching. The analysed educational program is based on the following principles: A discursive model of educational programs, a three-stage time model of educational programs (dedicated to preparing students before visiting the gallery, a specific educational program in the gallery and continuing education distributing the educational program) and connecting various components of visual art and other art forms. (Hajdušková, Fulková, Sehnalíková 2013)

The second level is based on the empirical study "The Process of Artwork Interpretation" (Ríhová,2018). In this study, the interpretation of an artwork in particular art education was analysed in comparison with the Czech Framework Education Program for Elementary Education and the European Network for Visual Literacy - ENViL and their model for visual literacy. The empirical study aims to compile the results of the research and the theoretical framework, including the curriculum, to identify the interpretation possibilities of students aged 11-13.

\section{Theoretical framework}

Discourses in contemporary art education based on cultural and visual studies and constructivist pedagogy. 


\section{Objectives}

The aim of the paper is to analyse and describe the specific situation in which the didactic transformation occurs through which the artwork becomes the subject of education.

\section{Methods}

1. The "Faces" case study is based on the reflection of the educational program "Faces - the Phenomenon of the Face in Video Art" at the Rudolfinum Gallery in Prague during August and September 2012.

For this education, we created three educational support materials - Worksheets, a Reading Book and White Boards. The education directly encouraged follow-up work at school. After the gallery education, follow-up instruction was taught in the educational area of Czech Language and Literature, Art Education and Drama Education. The case study includes learning outcomes from two teachers from two elementary schools in Prague (56 students aged 12-13). Research methods consist, participating observation, reflective balance of teachers, of preparation for teaching, focus group interviews with students, a discourse-based analysis of student testimonies, as well as worksheets and their visual art and essay in art and drama education.

2. The empirical study "The Process of Artwork Interpretation" is based on qualitative action research based on discourse analysis. Methods of research are participatory observation, transcription of audio recording of part of the lessons, discourse analysis of student worksheets, reflective papers from the teachers and reflective paper from the observers.

\section{Results}

The discourse-based educational model:

This part of the results is a diagram illustrating the process of interpretation in the observed art education. A detailed analysis of the audio records showed that the concrete education is based on discourse-based educational models. The discourse based educational model reveals the journey from the empirical spectator through pre-concepts to critical audiences, the path from perception to the interpretation of the artwork.

Figure 1. This visualisation reveals the relationship between the three terms - students/teacher/artwork in three phases.

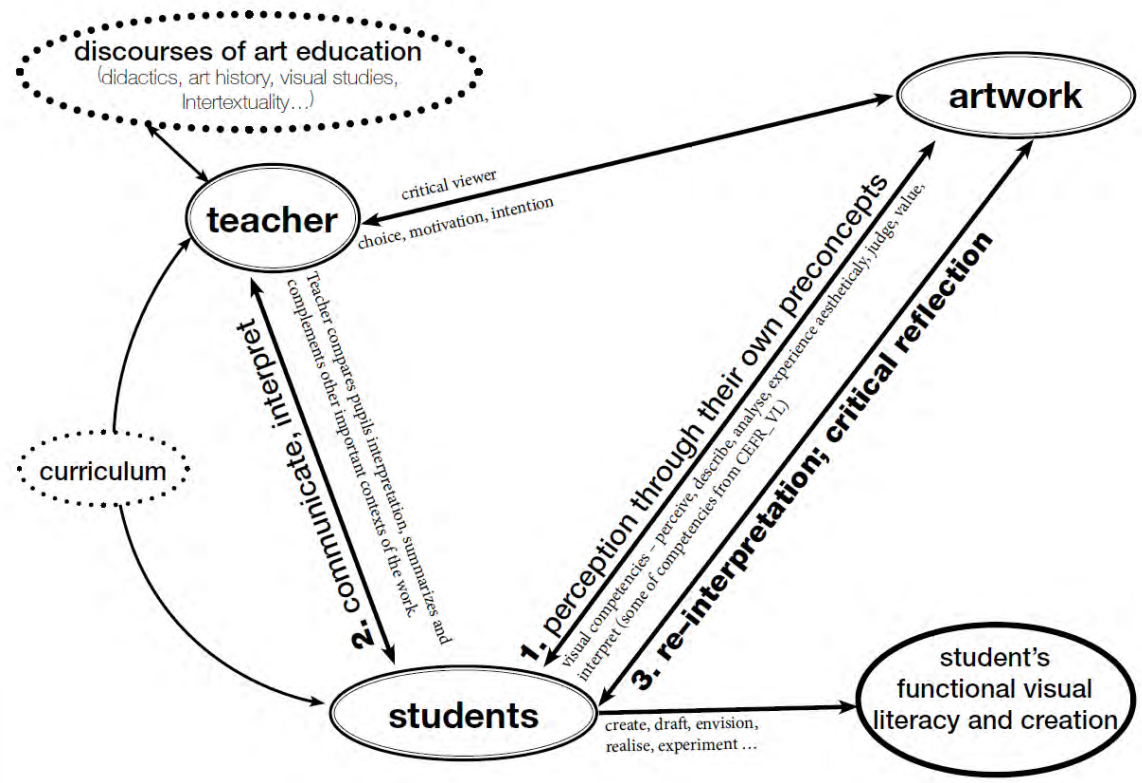

The first phase of the perception of the work is part of teaching when students are empirical spectators. The students' perception is through their own pre-concepts. In this visualisation, I use some visual competencies from the ENViL model - in this phase this is: perceive, describe, analyse, experience aesthetically, judge, value and interpret.

The second phase is about communication between the students and teacher. In this phase, the teacher played the role of initiator and mediator of the students' artwork perception and their own experience in their paths to art. Here visualisation reveals the power of discourse, which is the theoretical 
background of the field, including the curriculum. Visualisation reveals principles of artwork interpretation in concrete art education. The peer effect is a benefit of this phase.

The relationship between the teacher and artwork is about the teacher's reasons and their choice, motivation and intention - in this point of view the teacher is a critical viewer. artwork.

The most important is the third phase, when students re-interpret and critically reflect on the

This process has an impact on the student's increasing functional visual literacy and developing their own creativity.

The visualisation results of this learning strategy reveal art education to be a dialogue with a high level of student autonomy (learners as reflective practitioners) and with the concept of discourse as a medium organising audio-visual regimes.

The quality of interpretational process is affected by:

- the level of the student's critical thinking;

- the willingness to change to expand and reinterpret their own attitudes and opinions;

- the teacher's roles, mediating contexts from artwork discourse and art education;

- the teacher works with contexts to expand the understanding of the work and enrich their thinking;

- a language that is understandable to students;

- the processing of the youth's experience into an interpretational scheme runs counter to the deep-rooted notion that art can be understood only by experts and they speak of it as a very complicated method.

\section{Conclusions}

The research results confirm the current trends in approaches to teaching art history and contemporary art in art education and gallery education based on a high degree of student autonomy, the concept of a reflective practitioner, with the concept of discourse-based critical approaches.

The visual turn comes to the forefront of its critical analytical position - to watch, to think critically, to use its lived experience, and art education could be a relevant space to develop this kind of skills and visual competencies.

The results reveal the benefits of the subordination of teaching to learning.

The study revealed the gap between how the issue of interpreting the work of art in relation to the active involvement of a student's voice is perceived by the general public as opposed to a theoretical discourse. The curriculum presents us with a very challenging task in the form of expected outputs leading to a critical analytical position.

\section{Acknowledgements}

I would like to thank my Czech supervisors and colleagues: doc. PhDr. Jaroslav Bláha, PhD., Mgr. Věra Palánová, Mgr. Jana Bauerová, doc. PhDr. Marie Fulková, PhD. and PhDr. Leonora Kitzbergerová, Ph.D. The text is supported by Charles University, Project PROGRES Q17 2017 - 2021 Př́prava učitele a učitelská profese v kontextu vědy a výzkumu [Teacher Preparation and Teaching as a Profession in the Context of Science and Research].

\section{References}

Atkinson, D., (2006) School Art Education: Mourning the Past and Opening a Future. International Journal of Art \& Design Education, Vol. 25 No 1, 16-27.

Fulková, M., (2013) in Hajdušková, L., Kitzbergerová, L., Sehnalíková, V. (2012,2013): Galerijní a muzejní edukace 1 a 2 [Gallery and Museum Education]: In Prague: Charles University.

Mirzoef, N. (2012): Úvod do vizuální kultury [An Introduction to Visual Culture] Prague: academia.

Parsons, M. (2010), Interpreting Art through Metaphors. International Journal of Art \& Design Education, 29: 228-235.

Ř́hová, K., \& Bláha, L. (2017). Umělecké dílo a dětský divák. [Artwork and the Child Viewer] Výtvarná výchova, 57 (3-4), 72-80. Prague: Charles University.

Ř́hová, K. (2018) Proces interpretace uměleckého díla dětským divákem. [The Process of Artwork Interpretation by the Child Viewer] Výtvarná výchova: časopis pro výtvarnou a obecně estetickou výchovu školní a mimoškolní. Prague: Charles University.

Ŕíhová, K. Svatošová, Z. (2012). Educational Program to the exhibition Faces - the Phenomenon of Faces in Video Art. Prague: Rudolfinum Galerie.

Wagner, E. \& Schonau, D. (2016). Common European Framework of Reference for Visual Literacy Prototype. Münster, New York: Waxmann. 